\title{
The Evolution of the Ancient Way of the Warrior: From the Ancient Chronicles to the Tokugawa Period
}

\author{
Maria Paola CULEDDU*
}

\begin{abstract}
The term bushido is widespread today and involves history, philosophy, literature, sociology and religion. It is commonly believed to be rooted in the ancient "way" of the bushi or samurai, the Japanese warriors who led the country until modern times. However, even in the past the bushi were seldom represented accurately. Mostly, they were depicted as the authors thought they should be, to fulfil a certain role in society and on the political scene. By taking into account some ancient and pre-modern writings, from the 8th to the 19th centuries, from the ancient chronicles of Japan, war tales, official laws, letters, to martial arts manuals and philosophical essays, and by highlighting some of the bushido values, this article attempts to answer the questions how and why the representation of the bushi changed from the rise of the warrior class to the end of the military government in the 19th century.
\end{abstract}

Keywords: bushidō, samurai, shogunate, Japanese literature, history of Japan, gunki monogatari, legal codes, transformation.

\section{Razvoj starodavne poti bojevnika: od antičnih kronik do tokugavskega obdobja Izvleček}

Izraz bushidō je danes zelo razširjen in ga najdemo v zgodovini, filozofiji, literaturi, sociologiji in religiji. Navadno velja, da izhaja iz starodavne "poti« bushijev oz. samurajev, japonskih bojevnikov, ki so državo vodili vse do modernega časa. A tudi v preteklosti so bili bushiji le redko predstavljeni realistično. Najpogosteje so jih avtorji prikazovali take, kakršne so si jih zamišljali v njihovi vlogi v družbi in politiki. Ta prispevek bo poskušal s pomočjo nekaterih antičnih in predmodernih spisov iz obdobja od 8. do 19. stoletja, od antičnih japonskih kronik, vojnih zgodb, zakonov, pisem, priročnikov za borilne veščine do filozofskih esejev, in s poudarkom na nekaterih vrednotah bushidōja odgovoriti na vprašanji, kako in zakaj je od vzpona vojaškega razreda do njegovega zatona v 19. stoletju prihajalo do sprememb pri predstavah o bushijih.

Ključne besede: bushidō, samuraji, šogunat, japonska literatura, zgodovina Japonske, gunki monogatari, pravni kodeksi, preobrazba

Maria Paola CULEDDU, Sapienza University, Rome.

paola.culeddu[at]uniromal.it

I would like to express my sincere gratitude to the Editorial Board of Asian

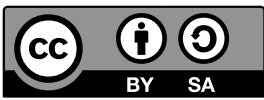

Studies for giving me the opportunity to publish this paper, to Prof. Valdo Ferretti, Gen. Giovanni Culeddu and the peer readers for their valuable suggestions, and to Kerry and Julian Flewitt for their diligent proofreading of this article. 


\section{Introduction}

In writing about bushido 武士道, one should first define the word itself. However, this is a difficult task, as the term is widespread today and is not univocal. It actually includes a long series of meanings and aspects. The term can refer to the conduct code of the samurai 侍 or bushi 武士, ${ }^{1}$ or to a specific mentality held by the Japanese people from the Meiji period on to the post-war Japanese business system, or to martial and some visual arts. Therefore, it involves not only history, but also philosophy, literature, sociology and religion.

Literally, bushido is a conceptualisation of the lifestyle and mind-set of the earlier warrior class in Japan. However, in today's collective imagination we are offered a simplistic, stereotyped, romanticised and folkloristic view of the Japanese samurai, who is seen as "frozen" and unchanged through time and history. What we are actually given is an image of a warrior who faces battle and death without hesitation, who wears fearsome masks and combat helmets and instills fear in his enemies, in peasants and city dwellers, who never shows his feelings and hides his pain, who longs to die in battle or for his Lord, who trains every day in martial arts and Zen meditation. His thought is always translated into action, and he follows a code of conduct resting on the principles of honour, loyalty to the Lord, and filial piety.

In recent years many authors have shown that bushido, as represented today-and consequently the modern depiction of the ancient samurai, is an "artificial" tradition, "entirely invented in the 19th century" (Saeki 2008, 894), and "dependent on political and cultural currents relating to Japan's modernization and the nation's attempts to redefine itself in the face of foreign 'others'." (Benesch 2011, ii). From the last decades of the 19th century, the authors of modern bushido constructed a "new" martial ethic, which was ideally rooted in the ancient customs and mind-set of the samurai, and which later became the pillar of the creation of the modern Japanese identity, nationalism, modern business system and society. ${ }^{2}$

As a historian, I will treat bushido precisely in its literal meaning of the "Way of the Bushi", the lifestyle, mind-set and conduct code of the earlier warrior class in Japan, or rather, the representation of the lifestyle, mind-set and conduct code of this class.

1 The word samurai originally referred to armed servants at the Imperial Palace or of a court noble in the Heian period, but in later and modern times it indicates Japanese warriors. In this essay, it is used in an interchangeable way with the term bushi.

2 Benedict Anderson defines a nation as "an imagined political community", and explains: "It is imagined because the members of even the smallest nation will never know most of their fellow-members, meet them, or even hear of them, yet in the minds of each lives the image of their communion". He also points out the objective modernity of nations to the historian's eye vs. their subjective antiquity in the eyes of nationalists. (Anderson 1991, 5-6) 
Actually, the word bushido only appeared in the Tokugawa period (1600-1868). ${ }^{3}$ But what it originally indicated originated much earlier. For example, in the ancient past of Japan, various expressions were used; "the way of the warrior" (tsuwamono no michi 兵の道 and mononofu no michi 武士の道), "the warrior's practice" (musha no narai 武者の習い), "the practice of those who hold the bow and arrow" (yumiyatoru mi no narai 弓矢とる身の習い), “the way of the bow and horse” (kyüba no michi 弓馬の道), “the way of loyalty” (chügi no michi 忠義之道), "the spirit of the warrior” (bushi no kokorogiwa 武士之心際), and so on.

The aim of this paper is an attempt to answer three questions: How was the "Way of the Warrior" recorded trough time? How did it change in connection with historical events, from the period before the establishment of the military government to the modern era? And why did it change?

After a brief historical introductory note, centred on the rise and power of the warrior class, I will show a selection of the main features of bushido as were expressed in writings from ancient literary works by courtiers and nobles, to some works issued in the pre-modern era.

I will then try to clarify how the original "Way of the Warrior" was "adjusted" and how the selection of values occurred during this transformation.

\section{A Brief Historical Outline}

The social stratification within the local structures and among the various clans (uji 氏) in pre-historic and proto-historic periods, and the struggles among various families, led to the rise of the Yamato court and the founding of an Imperial State around the figure of an Emperor of divine origins. Following Prince Shōtoku Taishi's "Constitution" (604), the first extant document in Japan relating to the sovereignty of a unique Emperor, ${ }^{4}$ the Taika Reform (646-) was based on the political and administrative structure of Tang China (618-907). It founded the Japanese government system under an Emperor and increased the Imperial Court's power at the expenses of the clans' (uji):

In Heaven there are not two suns: in a country there are not two rulers. It is therefore the Emperor alone who is supreme over all the Empire,

3 The most ancient written record where the word bushidō is found is Kōyō gunkan 甲陽軍鑑 (1616), a chronicle of the military deeds of the Takeda family (Kasaya 2014, 5).

4 Shōtoku Taishi's (574-622) "Constitution" dates back to 604 and is composed of 17 articles. Of Confucian and Buddhist influence, it sanctions the authority of the Emperor and encourages government functionaries and imperial subjects to follow moral virtues and carry out their specific duties. 
and who has a right to the services of the myriad people (Nibongi, transl. Aston 1896, 217).

However, during the Nara (710-784) and Heian (794-1185) periods, particularly the latter, the Emperor was "supreme over all the Empire" in name only. Power was actually held by some court families, monastic institutions or retired Emperors.

Between 690 and 702, a national military service, the Regiment system (gundansei 軍団制), was established within the centralisation policy. The Regiments were progressively reduced or eliminated in all the provinces except at the frontiers in 792, and substituted by an elitist chivalry corps (kondei 健览, “Stalwart Youth") subject to the provincial governors. The process of military decentralisation continued in the Heian period (794-1185), with the shoen 荘園 properties being developed into private lands, and exempted from central control or taxation (from the 10th century). Provincial officials and rich residents provided themselves with armed followers and acquired military skills themselves. The privatisation of the use of military skills, and the connections among different segments of the Court aristocracy and the local nobility in the provinces, led to the rise of military alliances, guided by the Warrior chiefs (bushi no töryō 武士の) 統領). The process leading to the rise of the bushi class on the Japanese political scene $^{5}$ and to the wars of the 12th century resulted in a final struggle (Genpei kassen 源平合戦, 1180-1185) between the military alliances, led by the Taira and Minamoto clans, and in the creation of the bakufu 幕府一the military government based in Kamakura (1192-1336)—led by the shoogun 将軍 Minamoto Yoritomo. The warriors were placed under a unique military authority and officially became the rulers of the country.

The Kenmu Restoration by Emperor Go-Daigo (r. 1318-1339) put an end to the first military government, which was followed by the Ashikaga bakufu (13381568) based in Kyōto. However, the Ashikaga shoggun could not stop the process of regionalisation caused by the provincial Governors (shugo 守護) and their retainers' ambition for autonomy. Their disinterest in and inability with regard to state administration, the weakening of the shoen system and the inheritance disputes that arose over land and property contributed to this process, and the Ashikaga thus progressively lost control of the provinces. In the 15 th century, a hundred-year civil war (the Sengoku period, from 1467) saw the appearance of new figures on the political scene- the daimyo 大名, who mainly came from various parts of the warrior class, and soon became the highest and only recognised authorities in their dominions ( han 藩).

$5 \quad$ On the rise of the bushi class in detail, see Friday 1992 and Duus 1969. 
In the middle of the 16th century, after the Portuguese brought firearms into Japan, the use of arquebuses (the so-called tanegashima 種子島) and cannons accelerated the process of stratification of the various daimyo in terms of strength and power, and the fighting strategies changed accordingly. Armies of foot soldiers (ashigaru 足軽) composed of peasants and guided by bushi were employed, and elaborate fortifications and stone castles were built in the place of simple wood fortifications and clan residences. The bushi were separated from the populace and bound to live in castle-towns with the clan head and his family.

By virtue of his military and diplomatic ability, the daimyō Oda Nobunaga was able to conquer half of the country and, after his death, the unification was completed by his General Toyotomi Hideyoshi (Momoyama period, 1568-1598). This paved the way for a new, highly centralised bakufu established in Edo (1603-1868) by Tokugawa Ieyasu. The process of separating the warriors from the populace started with Oda and Toyotomi, who enacted the "Sword Hunts", ${ }^{6}$ and was achieved during the Edo period with the establishment of a rigid caste system (mibunsei 身分制), which divided the population into four classes, with the samurai as the unquestioned rulers. They were a minority within the population (from 5 to 8\%), and the only group allowed to carry swords. They received an annual salary from the shögun or their daimyo for their service, and in the Edo period became bureaucrats within a structured political organisation.

After two and a half centuries of peace, Commodore Perry reached the Japanese coast in 1853, with the intention of opening its ports to trade with the United States. The following events led to the fall of the bakufu (Bakumatsu 幕末), and became fertile ground for the restoration of power to the Meiji Emperor in 1868.

\section{Japanese Warriors in Written Records, 8th to 19th Centuries}

\section{Ancient Chronicles, Court Diaries and Tales}

From a literary point of view, warrior figures first appeared in the two oldest written Japanese chronicles, the Kojiki 古事記 (712) and Nibonshoki 日本書紀 (720). ${ }^{7}$ The warriors are depicted as deities, or described as superhuman figures

6 The Sword Hunt Decrees (katanagari 刀狩) prohibited farmers from possessing weapons.

7 The chronicles described in an epic form the creation of the sacred land and islands of Japan by the deities and the descent of the first Emperor from the Sun Goddess, thus establishing a shinto pantheon and endorsing the concept of the Japanese sovereign's divinity and supremacy over the heads of the other clans (uji 氏). 
with mythical features. Their behaviour does not seem to respect any moral code, and they often succeed by means of their cunning.

In the first book of the Kojiki (1.18), Susanoo, "His-Swift-Impetuous-Male-Augustness", indomitable God of Sea and Storms, elder brother of the Sun Goddess Amaterasu omikami, arrived in the land of Izumo. Once there, he decided to help an old couple, whose seven daughters were devoured by the "eight-forked head and eight-forked tail" serpent, and their remaining daughter. He asked the couple to brew a strong sake and had the beast drink it. After the serpent fell asleep, he easily killed him.

Two aspects should be noted here. Firstly, Susanoo helped the old couple after asking them for their daughter in marriage in return, and thus he was moved by self-interest. Secondly, his treacherous deed resulted in a positive outcome, as in one tail of the beast he found the sword (Ama-no-murakumo-no-tsurugi), which later became one of the three symbols of Imperial power.

In another passage, young Prince Ōsu (then Prince Yamato Takeru) was sent off by his father, Emperor Keikō, to the "unsubmissive" Kumaso brothers (2.80.1-15).

Having combed down after the manner of girls his august hair which was bound up, and having put on his aunt's august [upper] garment and august skirt, he looked quite like a young girl. (transl. Chamberlain 1919, 256-7)

Disguised in such way, he was invited to join the Kumaso during a feast and then killed them. Before being hit, the younger Kumaso brother had time to show his admiration for the Prince, and offered him his own name:

[...] There are no persons in the West so brave and strong as we two. Yet in the Land of Great Yamato there is a man braver than we two,- - there is. Therefore will I offer thee an august name. From this time forward it is right that thou be praised as the August Child Yamato-take. (transl. Chamberlain 1919, 257)

Court diaries and novels flourished during the Heian period (794-1185), which show the customs, traditions and lifestyle of the nobles in Kyoto. Such diaries did not focus on samurai figures, but in some cases warriors were described, particularly in the diaries written by Court ladies. The bushi in the provinces were scorned for their bloody and violent actions. The samurai in service at the Imperial Palace were seen as physically powerful, but were despised for their rudeness and being far removed from the elegance and sophistication of the Court life. Generally they were considered to be servants, and enjoyed very low prestige among the Heian courtiers. 
The perception of the samurai figure partly changed after the establishment of the first bakufu.

The war tales (gunki monogatari 軍記物語, or senki monogatari 戦記物語), ${ }^{8}$ a new literary genre by the bushi themselves or court nobles, were written by various authors, mostly anonymous, in a mix of Japanese and Chinese. They collated tales which were previously transmitted orally by blind priests (biwahoshi 琵琶法師) as forms of rituals and for entertainment. The numerous versions differ as sections or episodes were added or eliminated over time. The warrior tales illustrated events which occurred from the second half of the 12th century onwards, sometimes with hyperbole and a celebratory tone, and described in detail battles, wars, the rise and fall of entire clans, deeds of uncommon warriors, and powerful weapons. The characters were sometimes stereotypes, but historical individuals were recognisable. The descriptions of their clothing, armour and horses provide us with valuable information on the customs of the time, and on the identities of the warriors themselves.

The greatness of the bushis skills, their superior physical strength and courageous attitude were often described. Some could handle "extra-ordinary" weapons.

Yet an enemy warrior called Saji Magoro, a resident of the province of Tamba, brought his horse up sideways in front of the west gate and easily slashed the bellies of three enemies with his five-foot sword, such a long sword as had never before been seen. (Taheiki, transl. McCullough 1959, 258)

An uncommon bravery characterised the heroes of war tales, who faced struggles without hesitation and with contempt for death.

Then Musashi-no-Saburoemon Arikuni of the Heike [...], having penetrated very deeply into the ranks of the foe, had his horse shot under him,

8 Among the gunki monogatari, some excel, such as The Tale of Hōgen (Hōgen monogatari 保元物語, about 1320), on the rebellion in 1156, The Tale of Heiji (Heiji monogatari 平治物語, 13th century), on the rebellion in 1159-1160, The Tale of the Heike (Heike monogatari 平家物語, ante 1330), on the struggle between the Taira and the Minamoto clans, and its extended version, on the years 1161-1185, the Tale of the Rise and Fall of Taira and Minamoto (Genpei seisuiki 源平盛衰記, early Kamakura period). The Kamakura bakufu events (years 1180-1266) are recounted in the Mirror of the East (Azuma kagami 吾妻鏡/東鑑, post 1266) and in the Jottings of a Fool (Gukanshō 愚管抄, circa 1219-20). Some gunki monogatari were also written in the Ashikaga period, such as the Chronicle of Great Peace (Taiheiki 太平記, circa 1370), recounting Emperor Go-Daigo’s (r. 1318-1339) ascent and restoration of the power and the Nanbokuchō period (1336-1392), and the Chronicle of Lord Nobunaga (Shinchōkōki 信長公記), a record of the Oda clan from 1544 to Nobunaga's death, while records of the exploits of military clans, such the Takeda's (Kōyō gunkan 甲陽軍鑑), and biographies, such as Hideyoshi's (Taikōki 太閤記), were issued in the Tokugawa period. 
and then, while he was fighting on foot, his helmet was struck from his head, so that he looked like a youth fighting with his long hair streaming in all directions. By this time all his arrows were exhausted, so he drew his sword an laid about him mightily until, pierced by seven or eight shafts, he met his death still on his feet and glaring fiercely at his enemies. After their leader had thus fallen his retainers gave up the fight and fled. (Heike monogatari, transl. Sadler 1918, 264)

A Buddhist influence "wrapped" the existences of these noble warriors with a sense of impermanence and a karmic logic of retribution for their actions. The war tales also recounted falling warriors and families, of their unhappy fates and their "humanity”. The Chronicle of Yoshitsune (Gikeiki 義経記), composed at the turn of the 15th century, told the story of Minamoto no Yoshitsune running away from his brother Yoritomo's warriors after helping him defeat the Taira and gaining power. The Tale of the Heike (Heike monogatari 平家物語) recounted the greatness of the Taira and the dramatic evanescence of their power and prosperity.

Additionally, values such as loyalty, filial piety and sense of honour are recorded for the first time in the war tales.

In such a context, repaying a debt was considered a major obligation.

I have no words to speak of your loyal hearts, who have cleaved to me thus far, not unmindful of your honour as warriors nor forgetful of past kindnesses, though it is known to you that the prosperity of the military is ended and my family is soon to be destroyed utterly. Profound indeed is my gratitude! How may I reward you, now that adversity overwhelms my house? I shall kill myself for your sakes, requiting in death the favours received in life. (Taheiki, transl. McCullough 1959, 310)

The importance of having a connection with the Court was a fundamental distinguishing feature. Many scenes described noble samurai announcing their name, title, and the deeds accomplished by them and their familiars (ujibumi yomi 氏踏 み読み), prior to facing the enemy in an individual struggle.

As mentioned before, some authors were Court aristocrats, and various passages still reflected a certain degree of disdain, especially for the lower level bushi, and for the samurai's absolute lack of literary culture and for their lifestyle, which included the killing of others.

But in the end, the image arising from the bushis extra-ordinary deeds, their daily facing of death, and austere lifestyle, especially in the later versions of the tales, 
raised the warriors above the common people in terms of prestige and respect. From this perspective, the battles in war tales were seen as noble endeavours, and even killings were not condemned, some of them being seen as honourable. For example, the practice of taking an enemy's head on the battlefield, especially if he was a high-ranking samurai or General, was common, as testified in the Gukanshō and the Azuma kagami.

\section{Law Codes}

After the bakufu was established, law codes and regulations were issued for the ruling warrior class. The law codes provide modern readers with valuable information on the military aristocracy (buke 武家) and the lifestyle samurai were asked to follow. These documents were of two different kinds: the official codes by the shogunate, and the official local codes by the Regional Barons (since the Sengoku period).

The Formulary of Adjucations (Goseibai shikimoku 御成敗式目, 1232) was enacted by the Hōjō regents during the Kamakura shogunate (1192-1333). Composed of 51 articles, it was aimed at making the bushi understand the principles of the law with regard to crime and punishment, inheritance and land rights. ${ }^{9}$

Two years before establishing the Muromachi shogunate (1338-1573), Ashikaga Takauji issued a second Code, the Law Code of the Kenmu Era (Kenmu shikimoku 建武式目, 1336), supplemental to Goseibai shikimoku, where he declared that "virtue resides in good government", which is "making people content", and claimed the right to defend the oppressed population from the Kenmu government and the Court nobles' abuses. The 17 articles of the Code were a sort of behavioural guidelines for the ruling samurai and recommended practicing frugality and rewarding men of integrity, righteousness and honour. ${ }^{10}$

During the Edo shogunate (1603-1868), the Various Points of Laws for Warrior Houses (Buke shohatto 武家諸法度, 1615, from hereon BSH) was enacted by Tokugawa Ieyasu (1543-1616), in thirteen articles. The Buke shohatto were reissued in $1629,1635,1663,1683$ and $1710,{ }^{11}$ and provide us with important evidence of specific behavioural standards and etiquette, and of an ethical ideal rooted among the samurai rulers.

$9 \quad$ Also, it set shugo and jito's duties, recommended respect for religious institutions and set up legal conflicts between the samurai and the Court nobility. On the Goseibai shikimoku see Hall and Mass 1974; Hall 1906.

10 On Kenmu shikimoku see Lu David J. 1997, 155-6; Mass 1998, 211-3.

11 On the Buke shohatto see Hall 1910, 286-319. 
The Buke shohatto opened with the importance of being culturally educated and practicing martial arts (bunbu 文武), even in times of peace (Art. 1). In the Nara and Heian periods being both literary and martial were considered fundamental in order to govern successfully. In this context bun was given priority over $b u$. During the first bakufu, bun and bu reflected the two different worlds of the court aristocrats and the warriors, respectively, while during the second bakufu bun was considered necessary to run a government. During the turmoil of the Sengoku war, in particular, it became essential for survival. Finally, in the Edo period the two aspects were inseparable, with priority being given to bu over bun (see Benesch 2014, 28 and below).

A clear Confucian influence appeared in the BS1635, formulated in collaboration with the Neo-Confucian Hayashi Razan, and in the BS1683. Here, loyalty and filial piety, ceremonial decorum and rectitude, are considered essential to a good ruler, along with martial skills. The BS1635 stated that he who did not behave in accordance with filial piety had to be subject to the Criminal Code. ${ }^{12}$ Moreover, samurai had to practice frugality and limit their gambling and parties. ${ }^{13}$

Loyalty to the shogun included strict control over the daimyo and service in the Edo period, ${ }^{14}$ and any disloyal behaviour had to be reported to the authorities. ${ }^{15}$

A ruler needed to select men of capacity for office and to distribute rewards or reproofs according to his subjects' actual merits. ${ }^{16}$

During the Edo period the practice of following one's Lord in death (junshi 殉死) was widespread among the vassals. The same day the BSH1663 was promulgated, this practice was verbally condemned, while a written prohibition appeared twenty years later, ${ }^{17}$ and was reinforced in $1710 .{ }^{18}$

One's clothing also had to reflect the distinction between lord and vassal, and one's social position (art. 10). ${ }^{19}$

12 BSH1635, art. 20. Hall 1910.

13 BSH1615/1629, art. 2. Hall 1910.

14 BSH1615, art. 9, and art. 2 of BSH1635 and BSH1663. Hall 1910.

15 BSH1615/1629, art. 7. Hall 1910.

16 BSH1615, art.13. Hall 1910.

17 BSH1683, art. 12. Hall 1910.

18 BSH1710, art. 16. Hall 1910.

19 Some other matters are also dealt with, such as weddings, the reparation of castles, or the importance of preserving the peculiarities of a domain not reporting secrets to people of other domains, and, from the BSH1635, with vessels, shrines and temples, roads maintenance, and the prohibition of the Christian sects. 
At a lower level, the Tokugawa shogun also enacted the Laws for the Hatamoto or Laws for the Gentry (Shoshi hatto 諸士法度, 1632, 1636 and 1663, from now $\mathrm{SH}) .{ }^{20}$ Provisions were given on various matters, such as house construction, military weapons, wedding celebrations, quarrels, disputes between farmers, hereditary succession and clothing. Particular emphasis was placed on the specific duties of one's service and office, to be performed without negligence, and on social position. ${ }^{21}$ Loyalty and filial piety were listed as necessary matters of cultivation at the beginning of the 1636 edition, together with the bunbu. ${ }^{22}$ Any opposition to governmental authority had to be avoided. ${ }^{23}$

Luxury was condemned, ${ }^{24}$ as well as personal disputes or disputes arising in the shogunate palace, which had to be firmly put down. ${ }^{25}$

In the turmoil of the Sengoku period, Law Codes were issued by the daimyō within the domains at war, with similar content, under the titles of Laws (batto 法度), Domain Laws (kokuhō 国法) and House Laws (kahō 家法), or also "Written on Wall” (kabegaki 壁掛), to assert their official character. ${ }^{26}$

\section{Family Letters}

Fundamental information on samurai rulers is provided by the "family precepts" (kakun 家訓). Directly addressed to sons or successors, these were private letters written by Provincial Governors (shugo 守護), wartime Regional Lords (sengoku daimyō 戦国大名) and Tokugawa Regional Lords (daimyō 大名) for didactic purposes and as a form of spiritual inheritance.

Exhortations to wise and rightful service and administration were given by the authors of the kakun. Heirs were encouraged to carefully examine and reward the virtuous behaviour of their subjects and to punish their wrong actions. They were also strongly advised to avoid the recommendations of untrustworthy men at their service. These letters also showed disapproval for a superficial behaviour, while they stated that the emulation of upright companions was essential.

20 On the Shoshi hatto see J.H. Wigmore 1975; J.W. Hall e M.B. Jansen 1968, Hall 1910.

21 SH1632, art. 1, 2 and 9. Hall 1910.

22 SH1636, art. 1. Hall 1910.

23 SH1636, art. 19. Hall 1910.

24 SH1636, art. 2 and 9. Hall 1910.

25 SH1636, art. 9 and 10. Hall 1910.

26 The Jinkaishū (塵芥集, 1536) by the Date clan of Mutsu domain and the Chōsokabe-shi okitegaki (長宗我部氏掟書, 1597) by the Chōsokabe clan of Tosa domain are examples of local laws codes. 
A personal tone was used in the letters. At the beginning of the 15 th century Imagawa Ryōshun powerfully criticised his younger brother Nagaaki, for being ungrateful to his Lord and parents, and absolutely disinterested in the virtues a leader should possess. ${ }^{27}$

You have minor offenders put to death without trial. But out of favouritism you pardon grave offenders. (Imagawajo, transl. Steenstrup 1973, 301)

You live in luxury by fleecing the people and plundering the shrines. In your actions you disregard the moral law by evading your public duties and considering your private benefits first. (Imagawajö, transl. Steenstrup 1973, 301)

Disheartened by being replaced in his office by the shögun, Ryōshun disapproved of the shameful attitude of Nagaaki, and aimed at convincing him to correct his behaviour in order to comply with the duties of his new post, often repeating the same points several times.

In contrast, there was no complaint in the letter written in 1673 by Itakura Shigenori, daimyō of the Karasuyama domain. His writing was composed of a series of suggestions and exhortations to Shigemichi, his “honest”, “sound” (kenjitsu 堅実) son.

Since you are honest, you will find that there are a lot of wrong things. Make friends with the people around you and ask for their opinion often, treat your subjects and the common people on friendly terms [...], discover their wisdom and potentials. (Itakura Shigenori Shigemichi e no isho, transl. Culeddu 2008, 192)

The authors of the kakun reflected in their letters the official Law's point on the fundamental nature of loyalty and filial piety, and on the need to reward men of good qualities, for "only a devoted and skilled warrior can be useful to his Lord" (Imagawajo, in Steenstrup 1973,301). Filial piety was strictly connected to loyalty to one's Lord. Itakura Shigenori started his letter by writing of $c h \bar{u} k \bar{o}$ 忠孝. Chū is the character for "devotion to one's Lord" and ko the character for "the loyalty to one's parents". Shigenori equated the two virtues, and maintained the absolute importance of both as the underlying principles of a virtuous behaviour.

Equally, they highlighted the importance of cultivating the martial arts together with learning of Confucian classics and military literature. ${ }^{28}$

27 Imagawa Sadayo (Ryōshun, 1326-1420) was a Military Governor (shugo 守護) and Military Deputy (tandai 探題) who served the shōgun in Kyūshu. His letter is addressed to his brother Nagaaki (then adopted, and addressed to as "son" in the letter), who replaced him by decision of the shogunate.

28 The Four Books and Five Classics texts of Confucianism are the Shisho gokyo 四書五経, while the Seven Military Classics are the Bukei shichisho 武経七書. 
It appears clearly from the Four Books, the Five Classics, and the Military Literature that he who can only defend his territory but has no learning, cannot govern well. (Imagawajö, transl. Steenstrup 1973, 307)

As you do not understand the Arts of Peace, your skill in the Arts of War will not, in the end, achieve victory. (Imagawajö, transl. Steenstrup 1973, 299)

Being lettered was not (or not only) a means to improve oneself mentally, but also met a practical need, the need to have administrative ability. As noted above, the importance of the bunbu (文武) was particularly stressed in the Tokugawa period. Indeed, just as in the BS, Itakura Shigenori expressed this concept in the first lines of his letter:

A Lord will find difficulties in ruling without culture. (Itakura, repr. 1974,34)

Learn in detail the Four Chinese classics, the Five books of Confucianism and the Seven texts of military art, and if you do not know the ideograms, ask someone to read them for you. (Itakura Shigenori Shigemichi e no isho, transl. Culeddu 2008, 192)

And:

Put literature on your left side, military art on your right. (Itakura Shigenori Shigemichi e no isho, transl. Culeddu 2008, 194)

But Itakura Shigenori also points out an additional element:

No matter how many books you read, you will not obtain any advantage if you do not control yourself. (Itakura Shigenori Shigemichi e no isho, transl. Culeddu 2008, 194)

Learning did not have to be a sterile knowledge, but the teaching in books had to be internalised. Only in this way could a samurai ruler take advantage of it.

\section{More Written Works about the Military Elite in the Tokugawa Era}

Literature on and by the bushi is not limited to gunki monogatari, laws and regulations and kakun. In the Tokugawa period, when the country was at peace, other works were composed, aimed at exploring and explaining the concepts and ethics connected with the "Way of the Warrior", and clarifying why the warrior class should rule in a pacified society. Yamamoto Tsunetomo's (1659-1719) 
Hagakure 葉隠 (Hidden by the Leaves, 1716), ${ }^{29}$ for example, is a series of moral teachings and anecdotes about the Lords and retainers of the Nabeshima clan, collected with the purpose of illustrating and explaining the Nabeshima samurai the various aspects of bushidō and good service. Daidōji Yūzan's (1639-1730) Budō shoshinshū 武道初心集 (Collection for Beginners in Budō, around 1730) ${ }^{30}$ is similar in scope, even if not anecdotic. Both books started defining the true meaning of being a samurai:

Bushidō, I have found out, lies in dying. When confronted with two alternatives, life and death, one is to choose death without hesitation. There is nothing particularly difficult; one has only to be resolved and push forward. (Hagakure, transl. Mukoh 1980)

One who is a samurai must before all things keep constantly in mind, by day and by night, from the morning when he takes up his chopsticks to eat his New Year's breakfast to Old Year's night when he pays his yearly bills, the fact that he has to die. That is his chief business. If he is always mindful of this, he will be able to live in accordance with the paths of loyalty and filial piety. (Budō shoshinshü, trans. Sadler 1988)

Firstly, the constant thought of death was far from being a desperate desire to die. Preparing to die and then being prepared to die were considered the source of loyalty and filial piety and of all the values of bushidō. This concept is well reflected in the ancient Latin saying sine spe, sine metu ("without hope, without fear"). Literally, it expressed a mental condition where there is no hope of survival and therefore no obstacle created by the thought of preserving one's own life. But de facto it didn't stick to death specifically, as it was also related to everything involved in duty, such as work, labour, inconveniences, commitment, responsibility, and the correct behaviour till death (if required). It stated that all of the above must be achieved, not in the expectation of receiving a reward or avoiding punishment, but because such behaviours were connected to a state, and perceived as adherence to some specific principles in an ethical sense. This is precisely the meaning of the above sentence from the Budō shoshinshü. Only with such a mental attitude could a samurai be able to act in compliance with his service and role, and consequently serve his Lord faithfully.

Secondly, it is worth noting that in the Budo shoshinshü the "Way of the Warrior" was primarily referred to as the Way of Loyalty and Filial Piety. Indeed, the latter appeared to be the "peaceful" side of bushidō in a pacified country.

29 The Hagakure is translated and known worldwide today. Originally called Nabeshima rongo 鍋島 論語 (Nabeshima Dialogues), it was kept within the Saga domain until the Meiji period.

Daidōji Yūzan was a military strategist and samurai. 
In the Hagakure, the bond between a Lord and retainer was considered so strong, that the term "love" was used to explain it.

The lord-retainer relationship, I believe, is similar to love. That is the fundamental spirit of retainer service far beyond logical reasoning. (Hagakure, transl. Mukoh 1980)

Another text is the Gorinsho 五輪書 (A Book of Five Rings, written towards 164045), by Miyamoto Musashi (1584-1645). Musashi spent some of his life apart from society as a rōnin (a samurai without lord), and devoted himself to perfecting his martial skills until he felt that he had found enlightenment in the "Way of Strategy". After fighting against Tokugawa Ieyasu at Sekigahara in 1600, he wandered over the country and won over sixty duels. His Gorinsho, on the "Way of Strategy", contained practical teachings to get victory over an enemy and showed the mental attitude of a successful samurai, and the thought behind this attitude, of Buddhist Zen inspiration. But even here the association of the concepts bun and $b u$, already treated in the above paragraphs, was held as necessary.

Bushi follow the two ways of literature and war. ${ }^{31}$ (Gorinsho, Miyamoto, 49)

Other writings on bushidō in this period are some essays of Zen inspiration, dealing with various matters.

In the Reiroshü 玲瓏集 (The Clear Sound of Jervels), the samurai and Zen monk Takuan Sōhō (1573-1645) 32 faced the issue of how to reconcile devotion to one's Lord with serving his successor after his death. As the practice of following one's Lord into death was forbidden by the bakufu, and since it was undoubtedly difficult in a pacified Japan to find occasions to sacrifice one's life for one's Lord, he found a solution in loyalty not to a specific master, but to "the Lord" as a concept (Reiroshü, 136), thus achieving the "Way of the Lord".

\section{A Change in the Tradition-From the Ancient Chronicles to the Neo-Confucian Bushidōo}

When the country was ruled by the Emperor and Court, the predecessors of the bushi were described as strong mythical figures in the Kojiki and Nibonshoki, and appeared as rude palace guards or provincial warriors in the Heian Court diaries

31 The exact verb used here is tashinamu (咾屯), usually translated with "have a taste for."

32 Takuan is also the author, among the other works, of Fudōchi shinmyōroku 不動智神妙録 (The Mysterious Records of Immovable Wisdom) and Taiaki 太阿記 (Annals of the Sword Taia). 
of the 10th century. After the bakufu was established and they became the rulers of the country, samurai started producing written documentation about their deeds, their political role and lifestyle after centuries of unwritten self-assertion of the "Way of the bushi", providing us with an energetic and complex self-view. Through time, the samurai's lifestyle, needs and principles changed along with the events that occurred over a time span of more than six centuries of warrior rule, and their literary representation changed accordingly.

The Taika reforms (646), based on the Tang Chinese model and aimed at creating a centralised state under Yamato Court rule, were enacted little more than fifty years before the Court permanently established itself in Nara (710). Prior to these reforms, the Yamato Emperor was a sort of primus inter pares and had to fight to impose his authority on the other uji heads. In search of legitimacy, the Court issued the Kojiki (712) and the Nibonshoki (720), epic chronicles recounting the creation of Japan and its Empire. The heroes in these chronicles asserted their right to supremacy by their extraordinary and lawless deeds, in a world where only the strongest could succeed and seize power, and some passages illustrated fallen heroes praising their treacherous enemies, as in the case of the Kumaso brothers.

During the rise of the bushi class the Court diaries mentioned samurai figures. These warriors were not superhuman heroes, but nonetheless the Court ladies depicted their strength and unrefined behaviour. Meanwhile, the military elite in the provinces orally transmitted its fundamental rules of conduct, within the warrior social class, from generation to generation.

During the wars of the 12th century, the supremacy of individuals and families arose from military ability in battle and successful endeavours. After the establishment of a military government, the bushi of the whole country were unified for the first time under a single commander, and acquired their own identity. Before receiving the title of shogun, Yoritomo had adopted Hachiman ${ }^{33}$ as patron deity of his family. Hachiman was later venerated as the protector of the whole samurai class. When a measure of order was restored, there was a need to establish its ethical legitimacy. Within this view, the gunki monogatari celebrated the heroic actions of all the samurai (not only of Minamoto's allies but also its enemies), with their strength and fighting ability.

The heads of the military alliances of the 12th century were aristocrats connected with Court nobles by blood ties, trained in martial arts and with armed followers and troops. They fought to increase their power and lands in the provinces and

33 In shintō Hachiman was identified with the mythical Emperor Ōjin (270-310), who is considered as an ancestor of the Minamoto clan. 
their influence at Court. The blood ties with courtiers were a source of distinguishing features, as I previously stated, but, again, these were seen more as a means to increase one's authority in the provinces or obtain posts in the capital, than an ideological legitimation in a period where the sanction of power was only given by success in battle. Indeed, in the gunki monogatari a sort of determination can be seen to distinguish oneself from the Court noble families (kuge 公家). This purpose was asserted in the different guiding principles (such as the sense of honour) and in the totally different lifestyles the two groups adopted.

Though some samurai behaviour is condemned in various episodes, the warrior tales claimed their moral superiority over the common people. This positive perception is rooted in the character of "necessity" guiding bushis actions. The ancient samurai were strictly connected to the land. (See Kanno 2006) At a medium and lower level the bushi in the provinces were based on their small plots of land, and success in battle meant survival for themselves and their families. Saeki Shin'ichi (2008) explains that the warriors in war tales fought for "fame". Being considered as a valiant samurai by one's Lord was the only means to get a reward, such as land, and therefore ensure prosperity for oneself, family and posterity. In this context, the "sense of honour" was rooted in a practical need. Indeed, while in some passages of the war tales betrayal was condemned (especially in some sections which are believed to have been added later), even actions clearly moved by self-interest and episodes of treachery were admired, as seen in the ancient chronicles.

For all the above reasons, a "fierce" and "wild" bushido is shown in the war tales, where fallen enemies were beheaded on the battlefield, and defeated samurai died wishing for revenge. Even if some of the heroes of the gunki monogatari appeared to follow some sort of code of ethics, these literary works recounting recent and violent historical events were far from being composed to explain the way of the bushi. Instead, they worked to legitimise the authority of the "new" rulers, who took power by virtue of their strength and cunning.

The Law Codes issued by the Hōjō regents and Ashikaga Takauji were a useful tool with regard to legal matters and guidelines for correct behaviour among the samurai, and the basis for the future codes of laws and regulations. As illustrated above, they also set a clear line between the excesses of Court nobles and religious institutions on one side, and the "right conduct" of the warrior class towards the population on the other, thus also giving legitimacy to the new rulers from a Confucian point of view.

During the Sengoku period (1467-1568), the imperial capital was destroyed and power was entirely decentralised, in favour of the local authority of the daimyo. Many similarities can be found with the situation in the wars of the 
12th century, in terms of violence and the constant struggle for survival, the forming of alliances and sudden betrayals. In one hundred years the battles among the domains led to the disappearance of many powerful military clans from the political scene, while some lower and medium rank samurai rose to power. Armed peasants were the norm, and many ronin wandered the country. Nonetheless, during the Sengoku wars the domains became self-sufficient political, administrative and economic entities. House Laws based on the ancient bakufu laws and letters of sengoku daimyō to their heirs were composed, and testified the domains' solidity and autonomy.

When Ieyasu came to power in 1600 and instituted a "confederation" of domains under the Tokugawa (the third bakufu), the local House Laws were not abolished, but kept as internal regulations, while the Buke shohatto were issued at a centralised level. The aim of the daimyös spiritual inheritance letters and of the local and central laws and codes was a practical one. They were to be functional with regard to domain administration, and show a ruler and samurai how he should act and what his mental attitude should be in times of peace. In those writings the neo-Confucian inspiration is evident. They illustrated a bushido where the literature was combined with martiality, where strong disapproval is expressed for superficial and careless behaviour, where a good ruler is able to select men of capacity for office and to fairly distribute rewards and punishments according to worthy or unworthy behaviour. As such, and as shown in laws and letters, bushidō corresponds to how a samurai and ruler should be.

During the Tokugawa period, with the crystallisation of society into separate classes and the transformation of warriors into salaried bureaucrats, the bushi needed instructions to face a new reality where they themselves were a transformed element in society. Even if most bushis lifestyles did not correspond to the one of the ideal figures depicted in the laws and daimyös letters, and even if these were issued for a practical purpose, these writings contributed to give ideological legitimacy to the privileges acquired with difficulty by the "new" samurai rulers, arisen from the Sengoku wars. From a Confucian point of view, the highest principles of bushido were the ideological reasons why the samurai were allowed to hold power (and swords). ${ }^{34}$

34 Nonetheless, the discourse on the legitimation process involves another aspect, deeply rooted in Japanese culture. As mentioned above, in the gunki monogatari noble warriors used to announce their genealogy and the deeds of their ancestors prior to engaging in a struggle with other high ranking samurai (ujibumi yomi). As it was in the past, also in pre-modern Japan blood ties were considered essential and were a necessary "guarantee" of a samurai's valour. Many samurai arisen to power during the Sengoku period surely "invented" or provided themselves with a "higher" genealogy than their actual one. Hideyoshi provided himself with the noble genealogy of the Toyotomi, and Tokugawa Ieyasu claimed descent from the Minamoto family. This descent allowed him to get 
During the Tokugawa period, the samurai kept training daily in martial arts and practicing Zen meditation and various arts, such as calligraphy, the tea ceremony and poetry. For a ruler the learning of his domain's history and of military and Confucian literature became essential to the land's administration. A wild bushido was thus substituted by a Confucian and interiorised bushidō.

The bushis "moral" superiority was considered absolute. Nonetheless, over time many merchants became wealthier than the samurai, many bushi became heavily indebted, and dissatisfaction against rulers spread in rural areas due to the peasants' hard lives. ${ }^{35}$ In this context, the role of the bushi forced to "live at peace" was questioned by some intellectuals of the time, most of whom were samurai themselves. They objected to most samurai's behaviours and lifestyles being distant from the ideal figure of a bushi ruler, noted the need to justify their role in society, and encouraged the warriors to stick to their "traditional" guiding principles, although what was highlighted did not belong to the first bushido.

A debate on Confucianism arose in the Tokugawa era, ${ }^{36}$ focusing on bushido as the "Way of the Rulers".

All these elements contributed to the systematisation of bushido that took place in the Meiji era (1868-1912), and is the focus of many scholars today (see, for example, Benesch 2014). After the struggles following the signing of unequal treaties with Western countries and the fall of the bakufu (1868), political power was restored to the Emperor's hands. The main aims of the new Japan were to free the country from foreign control by means of rapid modernisation, and to pursue an imperialistic policy towards other Asian countries. All the Emperor's subjects were necessary to this task, and, although the bushi disappeared as a class, a renewed bushido was taught to the Japanese people and presented to foreign countries. This new "Way of the Warrior" was presented as traditional, but was actually based on the Tokugawa philosophy and Western thought in terms of its values.

the title of shogun. Also, legitimation was sought in the continuity with the past, which constitutes another typical trait of Confucian inspiration. The oath to Ieyasu, taken by the daimyō at Nijō castle in Kyōto, was a direct reference to the first bakufu: "We will loyally respect the institutions of the Shogunate $(K u b o)$ as established for generations since the time of the General of the Right (Yorito$\mathrm{mo}$ ); out of regard for our own interest we will strictly obey any regulations which may hereafter be issued to us from Yedo" (Hall 1910, 286).

35 The peasants rose up more than three thousand times to ask for better living conditions in the Tokugawa period (Scheiner 1978).

36 The debate revolved around different interpretations of Confucianism by thinkers such as Ogyū Sorai (1666-1728), Ishida Baigan (1685-1744) (Lidin 1970 and Bellah 1978), and Yamaga Sōkō (1622-1685), while others, like Hirata Atsutane (1776-1843), rejected ideological systems imported from outside (primarily from China) and supported supposedly indigenous traditions (kokugaku 国学). 


\section{Conclusion}

The representation of the "Way of the Bushi" in Japanese writings has changed constantly over time. The various descriptions reflected specific needs, which included purposes of legitimation, teaching, guidance and entertainment.

Bushi were seldom represented accurately in such texts, and mostly they were depicted as the historical milieu required them to be at that time, and thus as the authors believed they should be, in order to fulfil a certain role in society and on the political scene. Since violence and strength were requirements in times of crisis and war, they became values within a wild busbido that described superhuman warriors, whose deeds arose from the need for survival, and that sanctioned non-chivalric endeavours such as treachery and murder. In contrast, since learning and respect for rules were requirements in times of peace, an interiorised bushidō described excellent administrators.

Similar paths of changing figures can be found in representations of the Medieval knights in the West. From soldiers on horseback with a fighting role within a single group, they became loyal servants of a Lord who rewarded them with feudal lands, guardians of the weak and damsels in distress, or members of monastic orders who fought and killed in the name of a God that preaches love.

As many scholars assert today, during the Meiji period (in particular in the years from 1880) a process of systematisation was performed by the government, which resulted in a "newly created" ethical code of conduct that they called bushidō, and which they believed to be rooted in the "traditional" "Way of the Warrior". As we can see from the events outlined in this paper, the process of systematisation started much before the modern era. But in the Meiji period there was a specific and conscious effort to build a value system for the Japanese people and to show to foreign countries, for political and state reasons. However, such goals were not the case in the previous periods.

Furthermore, it can be said that the representation of the "Way of the Warrior" reflected a need of the rulers, in terms of what image should be provided (more or less unconsciously) in order to give an explanation (faithful or completely invented) of the historical reality of the time. Over time, the literary means for this transmission changed. The chronicles became codes, laws, private letters, anecdotes and stories, essays, manuals and so on.

Nevertheless, the transformation of bushidō was a result of a more or less conscious strategy for the selection of values, necessary for the creation of the identity of the samurai class in ancient and premodern times, and of the nation in modern times. 


\section{References}

Anderson, Benedict. 1991 (1983). Imagined Communities: Reflections on the Origin and Spread of Nationalism. London and New York: Verso.

Aston, William George, transl.1896. Nihongi, Chronicles of Japan from the Earliest Times to A.D. 697, Transactions and Proceedings of the Japan Society. Supplement I, London.

Azuma kagami 吾妻鏡/東鑑, vol. 1-5, Kanei-ban Edition from the Koten Senshu Honbu Database 古典選集本文データベース (Selected Classic Literary Works Database), National Institute of Japanese Literature, Tokyo. JHTI (Japanese Historical Text Initiative, University of California at Berkeley). https://jhti.berkeley.edu/texthon17.htm, with an English translation by Minoru Shinoda (1960), The Founding of the Kamakura Shogunate 1180-1185. With Selected Translations from the Azuma Kagami. New York: Columbia U.P.

Bellah, Robert N. 1978. "Baigan and Sorai: Continuities and Discontinuities in Eighteenth Century Japanese Thought". In Japanese thought in the Tokugawa Period, 1600-1868. Methods and metaphors, edited by Tetsuo Najita and Irvin Scheiner, 137-52. Chicago: University of Chicago Press.

Benesch, Oleg. 2011. "Bushido: The Creation of a Martial Ethic in Late Meiji Japan." A thesis submitted in partial fulfilment of the requirements for the degree of Doctor of Philosophy in the Faculty of Graduates Studies (Asian Studies), The University of British Columbia, Vancouver.

Benesch, Oleg. 2014. Inventing the Way of the Samurai. Nationalism, Internationalism, and Bushido in Modern Japan. The Past and Present Book Series. Oxford: Oxford University Press.

Buke shohatto [1615], in Ono Kiyoshi 小野清. 1927."Buke Shohatto no Seitei 武 家諸法度の制定” (The Establishment of the Laws for the Military Houses), 2-4. Tokyo: Tokugawa Seido Shiryō 徳川制度史料.

Chamberlain, Basil Hall, transl. 1919. The Kojiki: Records of Ancient Matters. Rutland, Vermont, Tokyo: Charles E. Tuttle Company. Accessed Oct. 15, 2017. http://www.sacred-texts.com/shi/kj.

Culeddu, Maria Paola. 2008. "Daimyō Principles in the Tokugawa Era. An Essay on Itakura Shigenori and Some of His Contemporaries." RSO, 187-214.

Daidōji, Yūzan. 1988. The Code of the Samurai. A Translation of Daidōji Yüzan's Budō Shoshinshū. Transl. by Arthur L. Sadler. Rutland, Vermont \& Tokyo: Charles E. Tuttle Company.

Duus, Peter. 1969. Feudalism in Japan. New York: Alfred A. Knopf.

Friday, Karl F. 1992. Hired Swords: The Rise of Private Warrior Power in Early Japan. Stanford: Stanford University Press. 
Gukansho 愚管抄 (Jottings of a Fool) [1219 edition], from the Nihon Koten Bungaku Sakuhin Database 日本古典文学作品データベース (Japanese Classic Literary Works Database), Nihon Koten Bungaku Taikei 日本古典 文学大系 (Collection of Japanese Literary Classics), vol. 86, Iwanami Publishing Company, 1967. Online edition in JHTI, at http://sunsite3.berkeley. edu/jhti/NIJL\%20gateway.html, with an English transl. by Brown Delmer M. and Ishida Ichirō (1979), "The Future and the Past: A Translation and Study of the Gukansho, an Interpretative History of Japan Written in 1219", The Journal of Japanese Studies 6 (2): 383-8.

Hall, John Carey. 1910. The Tokugawa Legislation. Yokohama: Asiatic Society of Japan.

Hall, John Whitney, and Marius B. Jansen 1968. Studies in the Institutional History of Early Modern Japan. Princeton, New Jersey: Princeton University Press.

Hall, John Whitney, and Jeffrey P. Mass 1974. Medieval Japan. Essays in Institutional History. New Haven, London: Yale University Press.

Harris, Victor, trans. 1974. A Book of Five Rings, Woodstock, New York: The Overlook Press.

Itakura, Shigenori 板倉重矩. Repr. 1974. "Itakura Shigenori Shigemichi e no isho 板倉重矩重道への遺書.” Nihon Shisō Taikei 日本思想大系 27:34-36. Tokyo: Iwanami Shoten.

Jansen, Marius B. 1963. "Tosa in the Sixteenth Century: the 100 Article Code of Chōsokabe Motochika." Oriens Extremus 10: 83-108.

Kanno, Kakumyō 菅野覚明. 2006. Bushido ni manabu 武士道に学ぶ (Learning from the Bushido). Tokyo: Nihon Budōkan.

Kasaya, Kazuhiko 笠谷和比古. 2014. Bushidō. Samurai shakai no bunka to rinri 武士道一 侍社会の文化と倫理 (Bushido. Ethics and Culture of the Samurai Society). Tokyo: NTT Shuppan.

Kasaya, Kazuhiko 笠谷和比古.2016. Le Bushido : éthique et culture de la société des samouraïs. Fleurance: Le Drapeau blanc.

Kobayashi, Hiroshi 小林宏. 1978. “Domain Laws (bunkuku-hō) in the Sengoku Period with Special Emphasis on the Date House Code: the Jinkaishū." Acta Asiatica 35: 30-45.

Lidin, Olof G. 1970. Ogyü Sorai's Distinguishing the Way. An Annotated Translation of the Bendō. Tokyo: Sophia University.

Lu, David J. 1997. A Documentary History: the Dawn of History to the Late Tokugawa Period. Armonk, New York: M.E. Sharpe.

Mass, Jeffrey P. 1998. The Origins of Japan's Medieval World Courtiers, Clerics, Warriors, and Peasants in the Fourteenth Century. Stanford: Stanford U.P. 
McCullough, Helen Craig, transl. 1959. The Taibeiki: A Chronicle of Medieval Japan. Columbia: Columbia University Press. Accessed Sept. 15, 2017. https:// jhti.berkeley.edu/NIJL\% 20gateway.html.

Miyamoto, Musashi 宮本武蔵. Repr. 1986. Gorinsho 五輪書. Tokyo: Kamata Shigeo 鎌田茂男, Kabushiki Kaisha Kōdansha 株式会社講談社.

Nitobe, Inazō. 1901. Bushidō: The Soul of Japan. CITY: Shokabō.

Sadler, Arthur Lindsay, transl. 1918. The Heike Monogatari. Transactions of the Asiatic Society of Japan, vol. 46 (2): 1-278. Accessed Sept. 20, 2017. https:// archive.org/details/ TheHeikeMonogatari.

Saeki, Shin'ichi 佐伯真一. 2008. "Figures du samouraï dans l'histoire japonaise: Depuis Le Dit des Heiké jusqu'au Bushidō.” Annales. Histoire, Sciences Sociales 63 (4): 875-94.

Sakata, Yoshio 坂田吉雄. 1979. “Sengoku bushi 戦国武士 (Warrior from the Warrior State).” Nihon Shisōshi 日本思想史 10: 23-38.

Scheiner, Irwin. 1978. "Benevolent Lords and Honorable Peasants: Rebellion and Peasant Consciousness in Tokugawa Japan." In Japanese Thought in the Tokugawa Period, 1600-1868. Methods and Metaphors, edited by Najita Tetsuo and Irwin Scheiner, 39-63. Chicago: University of Chicago Press.

Steenstrup, Carl, transl.1973. "The Imagawa Letter: a Muromachi Warrior's Code of Conduct which Became a Tokugawa schoolbook." Monumenta Nipponica 28 (3): 295-316.

Takuan Sōhō 沢庵双方. Repr. 1970. Reirōshu 玲瓏集 (Collection of the Clear Sound of Jewels). In Reirōshū, Gendai Goyaku Zen no Koten 玲瓏集, 現代 語訳禅の古典, Ichikawa Hakugen 市川白弦, 119-64.

Wigmore, John Henry. 1975. Law and Justice in Tokugawa Japan. Materials for the History of Japanese Law and Justice under the Tokugawa. Tokyo: The Japan Foundation.

Wilson, William Scott, transl. 1986. Takuan Sōhō, The Unfettered Mind, Writings of the Zen Master to the Sword Master. Tokyo, New York and San Francisco: Kodansha International.

Yamamoto, Tsunetomo 山本常朝. Repr. 1974. Yamamoto Tsunetomo Hagakure 山本常朝. 葉隠, in Mikawa Monogatari - Hagakure 三河物語一葉隠, in Nihon Shisō Taikei 日本思想大系 vol. 26. Tokyo: Iwanami Shoten.

Yamamoto, Tsunetomo. 1980. The Hagakure - A Code to the Way of the Samurai. Translated by Takao Mukoh. Tokyo: The Hokuseido Press. 